\title{
Path Analysis on the Psychosocial Impact of Obesity or Overweight in Adolescents in Surakarta, Central Java
}

\author{
Yayang Kharistik Almasith1), Yulia Lanti Retno Dewi²), C.S.P. Wekadigunawan') \\ 1)Masters Program in Public Health, Universitas Sebelas Maret \\ ${ }^{2)}$ Faculty of Medicine, Universitas Sebelas Maret
}

\begin{abstract}
Background: Worldwide obesity shares 33 percent of adolescents body mass index. The prevalence of obesity has increased threefold since 1980. In Indonesia there are 10.8 percent of children aged 13-15 years who are obese. Obesity and overweight can cause various chronic diseases. Another important impact is psychosocial. Correct intervention and early prevention can reduce the psychosocial impact. This study aimed to determine the psychosocial impact of obesity or overweight on adolescents.

Subjects and method: This was an analytic observational study with cross-sectional design. The study was conducted at 6 junior high schools in Banjarsari and Jebres, Surakarta, Central Java, from October to November, 2017. A total sample of 160 junior high school students were selected for this study by purposive sampling. The dependent variables were depression, self-assessment, body image, eating disorder, and quality of life. The independent variables were obesity or overweight. Body mass index (BMI) was measured by body weight scale and microtoise. Data of other study variables were collected by questionnaire. The data were analyzed by path analysis.

Results: Obesity or overweight was directly associated with depression $(b=1.04 ; 95 \% \mathrm{CI}=0.32$ to 1.77; $\mathrm{p}=0.005)$ and bad body image $(\mathrm{b}=-2.35 ; 95 \% \mathrm{CI}=-3.20$ to $1.49 ; \mathrm{p}<0.001)$. Depression was directly associated with eating disorder $(b=0.55$; CI $95 \%=-0.87$ to $1.18 ; \mathrm{p}=0.091)$ and poorer quality of life $(\mathrm{b}=-0.64 ; 95 \% \mathrm{CI}=-1.34$ to $0.69 ; \mathrm{p}=0.077)$. Good body image was directly asssociated with positive self-assessment $(\mathrm{b}=2.71 ; 95 \% \mathrm{CI}=1.89$ to $3.52 ; \mathrm{p}<0.001)$.

Conclusion: Obesity or overweight in adolescents is directly asssociated with depression and bad body image. Obesity or overweight is indirectly associated with negative self-assessment, eating disorder, and poorer quality of life.
\end{abstract}

Keyword: overweight, obesity, psychosocial, path analysis

\section{Correspondence:}

Yayang Kharistik Almasith. Masters Program in Public Health, Universitas Sebelas Maret, Jl. Ir. Sutami 36 A, Surakarta 57126, Central Java. Email: ycharistik@yahoo.com.

Mobile: +6281229474445

\begin{tabular}{l}
\hline BACKGROUND \\
\hline Obesity and overweight become health \\
problems almost all over the world. World \\
Health Organization (WHO) states that \\
obesity and overweight have become global \\
epidemics. They are now threats for the \\
society and population that develop fast in \\
some countries. In 2008, it is reported that \\
there were 200 millions of male population \\
and 300 millions female population were \\
obese. 65\% of the world population who \\
obese and overweight have higher risks to
\end{tabular}

pass away because of malnutrition (WHO, 2016).

Adolescence is a period where the physical, psychological and intelectual development of an individual happen so fast. According to WHO (2016), adolescents are those who are in the age of 10-19. The number of adolescents in the age of 10-19 in Indonesia based on the census done in 2010 was about 43.5 millions or about $18 \%$ from the total population. 
Journal of Epidemiology and Public Health (2018), 3(2): 105-117

https://doi.org/10.26911/jepublichealth.2018.03.02.01

In 2013, there were 12 billions adolescents or about $17 \%$ of the world population and it is the greatest adolescents in history (Cherry et al., 2017). The USA states that obesity and overweight problems become a significant health problem. There is an increase for about $33 \%$ obese and overweight adolescents, it is about three times since 1980 and the prevalence of obesity in adolescents has increased two times since (Baghci dan Harry, 2013).

Indonesia is now facing two nutrition problems. Malnutrition has not been fully solved. On the other hand, Indonesia has faced a problem about obesity and overweight. The prevalence of obesity and overweight keeps increasing and now it is estimated that there are 100 billions people in the world are obese. Meanwhile, the prevalence of obesity and overweight in Indonesia has also been in the state of dangerous. Based on the data from Basic Health Research (2013), obesity has become a national problem in children aged $13-15$ or about $10.8 \%$ consisting of $8.3 \%$ fat and 2.5 obese or overweight. The prevalence of obese and overweight adolescents in Central Java has reached 9.5\%, meanwhile in Surakarta, the prevalence is higher than other provinces which is $10.9 \%$.

Based on the data from Health Center Profile of Surakarta (2015), there were 6.829 adolescents did obesity check up, and there were 2.861 (41.89\%) who were obese. The greatest prevalence was in Banjarsari district which was about $68.57 \%$ of them who were obese. Jebres district was in the second place with $27.85 \%$.

Obese adolescents tend to be obese too when they are adults and it potentially can cause various cardiovascular and metabolic diseases. According to WHO data, more than 1.4 billion adults are iverweight and 2.8 million adults die each year because of obesity and overweight that cause various chronic diseases such as diabetes and heart diseases. Obesity has also been linked to other broad spectrum, other than diabete type 2, there are also degenerative diseases, including metabolic abnormalities and certain forms of cancer. It is reported that $80 \%$ of it causes diabetes type 2, 70\% of it causes cardiovascular diseases, and $42 \%$ cause breast and colon cancer. Obesity is a major factor behind 30 gall bladder disorders, which involves surgery and 26 high blood pressure incidents (Cherry et al., 2017).

Another important impact is the impact on growth and development of psychosocial aspects. Overweight adolescents often suffer from social bias, prejudice and discrimination, not only by public society but also health professionals, and this may make them reluctant to seek for medical help. According to Roberts and Duong (2013) in his research, they mentioned that obesity is at greater risk for poor mental health. Adapting to age and income of family and also gender, the association for poor mental health gets stronger. Another study was conducted by Endah Pujiasti et al., (2013) which mentioned that the incidence of psychosocial problems were higher in obese adolescents than in those with normal nutrition state. Among the obese adolescents, there were $15 / 31$ of them experiencing psycho-social problems. The obese adolescents group had significantly higher relevance of psychosocial problems compared to the normal nutritional group.

\section{SUBJECT AND METHOD}

\section{Study Design}

This was an observational analytic study with a cross sectional design. All the variables studied in both the independent and the dependent variables were measured at the same time. The study was conducted in six junior high schools in 
Jebres and Banjarsari district, Surakarta. The data were collected from October to November 2017.

\section{Population and Samples}

The target population of the study were all middle adolescents (14-16 years old) at Junior High Schools in Surakarta. Source population (population affordable) were middle adolescents (14-16 years) who were obese and overweight in junior high schools in Banjarsari and Jebres districts, Surakarta and normal adolescents for about 160 subjects with 2: 1: 1 ratio of normal weight adolescents: overweight adolescents: obese adolescents.

The samples were taken using random sampling for school selection and purposive sampling to determine the students. It was done on the basis of consideration that the desired elements were present within the subject members taken. There were seven variables in this study. The dependent variables were depression, self-assessment, body image, eating disorders and quality of life. The independent variable were obesity and overweight adolescents.

\section{Variables Operasional Definitions}

Obese was defined as the body mass index with percentile scales more than or equal to 95 percentile according to CDC classification of 2015 .

Overweight was defined as indicated by body mass index with percentile scale 85 - less than 95 percentile according to CDC classification of 2015 .

Depression was defined as an emotional response characterized by experiencing one or more symptoms of mood, such as feeling depressed, guilty, helpless, withdrawn, anxious, over sensitive and have the desire to harm othemselves or others.
Self-assessment was defined as the assessment to themselves of how they are worthy for others.

Body image was defined as how students are sure of their appearance and how their feelings about their body are.

Eating disorders was defined as disorders in their eating behavior, such as reducing or increasing levels and portions of food when eating.

Quality of life was defined as a condition whereby one can remain physically, psychologically, socially and spiritually comfortable and optimally exploit his life for the happiness of themselves and others.

\section{Data Collection}

The data were collected using questionnaires. The instrument which underwent reliability test was self assessment, body image, and eating disorders questionnaires. Based on the reliability test, the item-total correlation of self asessment variable was $r$ arithmatic $\geq 0.22$ and Cronbach Alpha $\geq 0.67$. All items were proven to be reliable.

\section{Data Analysis}

This study was a path analysis study. The analysis was done by measuring the direct and indirect effect of every independent variable to the dependent one. The procedures included model specification, model identification, model suitability, parameter estimation and model respecification.

\section{Research Ethic}

The research ethics included informed consent, anonymity, confidentiality and ethical clearance from RSUD Dr. Moewardi, Surakarta.

\section{RESULTS}

\section{Sample Characteristics}

The characteristics of study subjects are presented in Table 1.

Table 1 displays the characteristic that most of subjects are male (57.5\%). There 
Journal of Epidemiology and Public Health (2018), 3(2): 105-117

https://doi.org/10.26911/jepublichealth.2018.03.02.01

were 97 of them whose fathers' educational background were still low (60.6\%). There were also 97 of them whose fathers' educational background were still low (60.6\%). Most of their parental occupation

Table 1. Study Subject Characteristics

\begin{tabular}{llll}
\hline \multicolumn{1}{c}{ Characteristics } & n & \% \\
\hline Gender & 92 & 57.5 \\
Male & 68 & 42.5 \\
Female & & 60.6 \\
Paternal Educational & 97 & 39.4 \\
Low (<Senior high school) & 63 & 60.6 \\
High ( $\geq$ Senior high school) & & 39.4 \\
Maternal Educational & 97 & 86.9 \\
Low (<Senior high school) & 63 & 13.1 \\
High ( $\geq$ Senior high school) & & \\
Enternal Occupation & 139 & 45.6 \\
Civil Servant & 21 & 54.4 \\
Maternal Occupation & & \\
Career Woman & 73 & 58.8 \\
Housewife & 87 & 41.3 \\
Number of children & & \\
$<2$ & 94 & 66 & \\
$\geq 2$ & & \\
\hline
\end{tabular}

\section{Path Analysis}

Figure 1 shows a structural model after estimating data process using Stata 13 application and SEM (Structural Equalization Modeling) program. Figure 1 also presents the direct and indirect impact of psychosocial effects of obesity and overweight.

The degree of freedom $(\mathrm{df})=27$ was over-identified so that path analysis can be performed. This study was in accordance with the sample data shown by the saturation model and also the regression coefficient which was more than zero and statistically significant, so there is no need to re-create the path analysis model.

Table 2 shows that there was a relationship between obesity or overweight of adolescents and depression and it was statistically significant. Adolescents who were obese or overweight were more likely to experience depression $(\mathrm{b}=1.04 ; 95 \% \mathrm{CI}$ $=0.32$ to $1.77 ; \mathrm{p}=0.005$ ). were entrepreneur (86.9\%). Their mothers were mostly housewives, for about 87 participants (54.4\%). Most of them have brothers/sisters which was $<2$ (58.8\%).

There was a relationship between obesity or overweight and body image. Adolescents who were obese or overweight were more likely to have low body image (b $=-2.35 ; 95 \% \mathrm{CI}=-3.20$ to $1.49 ; \mathrm{p}<0.001$ ).

There was a relationship between eating disorders and the quality of life of adolescents. Adolescents with eating disorders were more likely to have a lower quality of life. ( $\mathrm{b}=-1.72 ; 95 \% \mathrm{CI}=-2.46$ to 0.98 ; $\mathrm{p}<0.001$ ).

There was a relationship between maternal education and obesity or overweight. Adolescents with low levels of maternal education were more likely to be overweight and obese $(\mathrm{b}=-0.68 ; 95 \% \mathrm{CI}=$ -1.36 to $-0.14 ; \mathrm{p}=0.046$ ).

There was a relationship between maternal employment status and obesity or overweight. Adolescents who had working mother have a greater likelihood of being overweight and obese. $(\mathrm{b}=0.77 ; 95 \% \mathrm{CI}=$ 0.11 to $1.44 ; \mathrm{p}=0.022$ ). 
Almasith et al./ Path Analysis on the Psychosocial Impact of Obesity

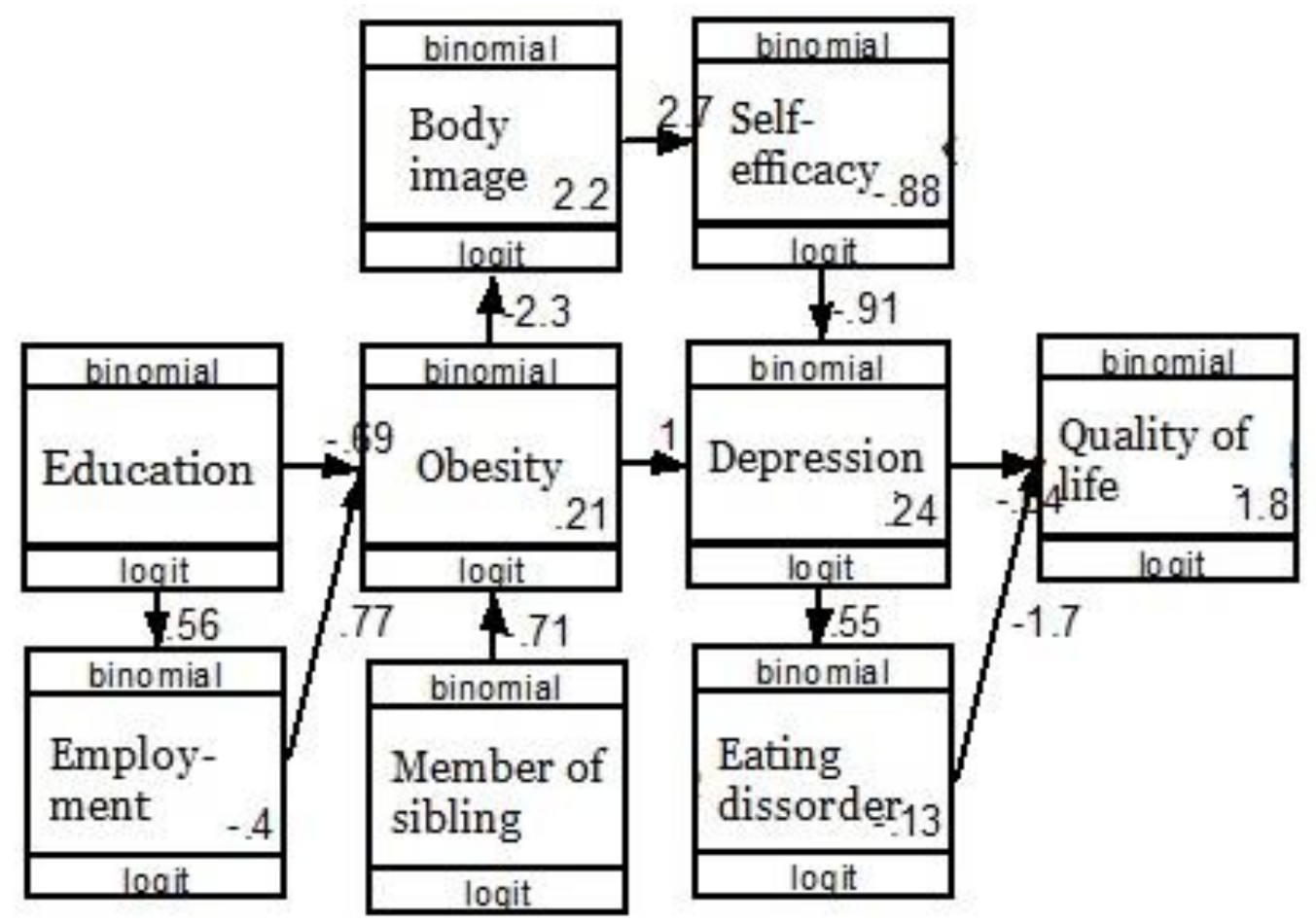

Figure 1. Structural model of path analysis

Table 2. The path analysis result of psychosocial impacts of obesity or overwight on adolescents

\begin{tabular}{|c|c|c|c|c|c|}
\hline \multirow[b]{2}{*}{$\begin{array}{c}\text { Dependent } \\
\text { Variables }\end{array}$} & \multirow[b]{2}{*}{ Independent Variables } & \multirow[b]{2}{*}{$\begin{array}{c}\text { Path } \\
\text { Coefisien }\end{array}$} & \multicolumn{2}{|c|}{ CI 95\% } & \multirow[b]{2}{*}{$\mathbf{p}$} \\
\hline & & & $\begin{array}{c}\text { Lower } \\
\text { limit }\end{array}$ & $\begin{array}{l}\text { Upper } \\
\text { limit }\end{array}$ & \\
\hline \multicolumn{6}{|l|}{ Direct Effect } \\
\hline Depression & $\leftarrow$ Obesity or overweight & 1.04 & 0.32 & 1.77 & 0.005 \\
\hline Body image & $\leftarrow$ Obesity or overweight & -2.35 & -3.20 & -1.49 & $<0.001$ \\
\hline Eating disorder & $\leftarrow$ Quality of life & -1.72 & -2.46 & -0.98 & $<0.001$ \\
\hline Obesity or overweight & $\leftarrow$ Maternal education & -0.68 & -1.36 & -0.14 & 0.046 \\
\hline Obesity or overweight & $\leftarrow$ Maternal employment & 0.77 & 0.11 & 1.44 & 0.022 \\
\hline Obesity or overweight & $\leftarrow$ Number of sibling & 0.71 & -1.37 & 0.76 & 0.034 \\
\hline \multicolumn{6}{|l|}{ Indirect Effect } \\
\hline Depression & $\leftarrow$ Self-efficacy & -0.91 & -1.68 & -0.15 & 0.020 \\
\hline Self-efficacy & $\leftarrow$ Body image & 2.71 & 1.89 & 3.52 & $<0.001$ \\
\hline Quality of life & $\leftarrow$ Depression & -0.64 & -1.34 & 0.69 & 0.077 \\
\hline Eating disorder & $\leftarrow$ Depression & 0.55 & -0.87 & 1.18 & 0.091 \\
\hline $\begin{array}{l}\text { Maternal education } \\
\text { Log likehood }=-666\end{array}$ & $\leftarrow$ Maternal education & 0.56 & -0.08 & 1.19 & 0.089 \\
\hline
\end{tabular}

There was a relationship between the number of siblings and obesity or overweight. Adolescents with fewer siblings $(<2)$ were more likely to be obese and overweight $(\mathrm{b}=0.71 ; 95 \% \mathrm{CI}=-1.37$ to $0.76 ; p=0.034)$.

There was a relationship between body image and depression through self- efficacy. Adolescents with low self-esteem were more likely to get depressed $(\mathrm{b}=$ $0.91 ; 95 \% \mathrm{CI}=-1.68$ to $-0.15 ; \mathrm{p}=0.020$ ).

There was a relationship between obesity or overweight and self-efficacy through body image. Adolescents with a lower body image more likely to have low 
Journal of Epidemiology and Public Health (2018), 3(2): 105-117

https://doi.org/10.26911/jepublichealth.2018.03.02.01

self-efficacy $(\mathrm{b}=2.71 ; 95 \% \mathrm{CI}=1.89$ to 3.52 ; $\mathrm{p}<0.001$ ).

There was a relationship between obesity or overweight and quality of life through the depression. Adolescents with greater depression have a lower quality of life $(\mathrm{b}=-0.64 ; 95 \% \mathrm{CI}=-1.34$ to $0.69 ; \mathrm{p}=$ 0.077).

There was a relationship between obesity or overweight and eating disorder through depression. Adolescents who experience depression have a greater likelihood of having eating disorder $(\mathrm{b}=0.55 ; 95 \% \mathrm{CI}$ $=-0.87$ to $1.18 ; \mathrm{p}=0.091$ ).

There was a relationship between maternal education and obesity or overweight through maternal employment status $(\mathrm{b}=0.56 ; 95 \% \mathrm{CI}=-0.08$ to $1.19 ; \mathrm{p}=$ o.089).

\section{DISCUSSIONS \\ 1. The effect of obesity or overweight in depression.}

The result of the analysis showed that obesity and overweight in adolescents had a direct impact on depression cases in a positive way.

Obesity is defined as having overweight body due to the accumulation of fat in the body. While overweight is defined as body weight condition which exceeded normal body weight (Centers for Disease Control and Prevention, 2017).

The obesity that caused a depression can be biologically seen. Obesity or overweight are conditions of inflammation due to the weight gain that has been shown to activate the inflammatory pathways in the body, and the inflammation can cause depression. Hypothalamus Pituitary Adrenal axis (HPA axis) has a role in this case. The dysregulation of the HPA axis is involved in obesity and dysregulated of HPA axis leads to depression (Pasquali and Vicennati, 2000). Moreover, the obesity involves an increased risk of diabetes mellitus and insulin resistance that can cause changes in the brain and increase the risk of depression (Shoelson et al., 2007).

In addition to biological mechanisms, the depression that is caused by obesity and overweight can be explained in a psychological mechanism. Depression is an emotional response and the characteristics are desperation, reduced motivation, low self-esteem, slow thinking process, psychomotor retardation and also eating and sleeping disorders. Overweight, obesity and the perception can increase psychological pressure (Atlantis and Ball, 2008). Some people still think and believe that being skinny is a form of beauty and beauty is considered as social acceptance and sociocultural factors. It increases body dissatisfaction and reduces self-esteem, which is a risk factor for depression. Disorganized eating and sleep habit and also physical pain are direct consequences of obesity, and it can increase the risk of depression (Derenne and Beresin, 2014).

Similar result can be seen in a study conducted by Floriana. Luppino et al., (2010) entitled "Overweight, Obesity, and Depression: A Systematic Review and Meta-analysis of Longitudinal Studies". This literature study consists of 15 studies from PubMed, PsycINFO and EMBASE databases which were selected according to the criteria. The results of the meta-analysis showed that people who are obese have 1.5 times more likely to have depression and it was statistically significant.

A study by Masdar Huriatul et al., (2016) showed that $17.4 \%$ of subjects experienced depression, $65.2 \%$ experienced anxiety, and $34.8 \%$ experienced stress. The results showed that there was a meaningful relationship between depression, stress, and obesity. 


\section{The effect of obesity or overweight on body image.}

The result of analysis showed that obesity and overweight directly affect the body image negatively.

Body image is a person's judgment of her/himself to be confronted or shown to others. Body image also illustrates how a person can see her/himself positively or negatively.

For the adolescents who have obesity or overweight, the most common problem is self-confidence. A thin body is considered attractive and a symbol of beauty. This assumption fosters the confidence for skinny adolescents, but on the contrary it can lead to confident problem in adolescents with obesity or overweight. Those assumptions may also cause the adolescents with obesity or overweight to feel dissatisfaction with themselves. Repeated negative social experiences can accumulate overtime and lead to negative psychological impacts such as higher body dissatisfaction (Alleva et al, 2014).

This effect will affect more to individuals who are always exposed to the stigmatization which is related to weight and body shape. The feeling of dissatisfaction with their own body will lead to selfconcept or negative body image in adolescents (McClanahan et al., 2009).

A study by Ozmen Dilek et al., (2007) showed a similar result. It is stated that adolescents with obesity and overweight on Body Mass Index have a significant relationship as it affected the body image and satisfaction with their body. The score of OR is 0.60 , which means that the adolescents with obesity and overweight are 1.7 times higher to have a risk of negative body image than adolescents with normal weight.

\section{The effect of obesity or overweight on self-efficacy}

The result of analysis showed that obesity and overweight indirectly affect the selfassessment through body image in a positive way.

Self-assessment is someone's self efficacy of the ability that she/he has. There are numerous factors that affect someone's self-assessment, one of them is about how the individual can accept her/his physical appearances. When individuals are satisfied and confident about their physical appearances, then these individuals will have high self-rank, and vice versa.

Obesity and overweight can lead to low self-assessment through three aspects, namely social discrimination, low body image and feelings of guilt and shame on their own body.

Social discrimination is still often experienced by the obese individuals. Most obese adolescents have difficulty in making friends or approaching individuals of the opposite gender. Therefore, the individuals will be more likely to experience inferiority.

The second aspect is that the obesity lead to low self-assessment through low body image. Most obese individuals find themselves "ugly" or unattractive. The idea of a fat body is believed to be a personal failure because it diverges from the ideal body. This greatly affects their confidence to interact or socialize with others. Therefore, adolescents with obesity and overweight may experience a confidence crisis that causes them to experience a decrease in satisfaction and confidence in themselves and it leads to a low selfassessment (Klaczynski et al., 2004).

Moreover, feelings of guilt and shame for the body is often felt by most individuals who are obese. Individuals who are obese tend to avoid physical activities such as exercise. This is because of their body's 
Journal of Epidemiology and Public Health (2018), 3(2): 105-117

https://doi.org/10.26911/jepublichealth.2018.03.02.01

inability to run fast, excessive sweating or other health problems associated with obesity and overweight that they experienced. As a result, these individuals feel less productive and less useful compared to their peers. This is the reason that can lead to guilt and inferiority.

Similar results from Alvani et al. (2016) suggest that self-assessment and sex differences were significantly correlated with weight status and the score was $(\mathrm{p}=$ o.02). Students with obesity and overweight have lower self-assessment than students with normal weight. Low selsassessment was mostly found in female students with obesity and overweight.

\section{The effect of obesity or overweight on eating disorder}

The result of analysis showed that obesity and overweight of adolescents can indirectly affect eating disorders through depression in a positive way.

Obesity or overweight can lead to depression by biological and psychological mechanisms. Biologically, obesity or overweight are considered as conditions of inflammation, as it is proven in activating the inflammatory pathway in the body. While the inflammation it-self has a role in the occurrence of depression. Hypothalamus Pituitary Adrenal axis (HPA axis) has a role in this case. Obesity involves the dysregulation of the HPA axis and it is involved in the occurrence of depression (Pasquali and Vicennati, 2000). Moreover, obesity leads to an increased risk of diabetes mellitus and an increase in insulin resistance that can cause changes in brain and increase the risk of depression (Shoelson et al, 2007).

Psychologically, depression is an emotional response with despair characteristics, reduced motivation, low selfesteem, slow thinking process, psychomotor retardation, and also eating and sleeping disorders. Overweight, obesity and perception can increase psychological pressure (Atlantis and Ball, 2008). Some people still believe that skinny is a form of beauty, beauty is considered as social acceptance and sociocultural factors. It increases body dissatisfaction and reduces self-esteem, which is a risk factor for depression (Derenne and Beresin, 2014).

Lubis (2016) categorizes the symptoms of depression into emotional, cognitive, motivational, and physical symptoms. Eating disorders is one of the symptoms of depression in the emotional and physical categories. Emotional symptoms are changes in feelings or behaviors and they lead to direct result of emotional conditions such as a decreased mood, negative view of themselves, no excitement, and feeling of dissatisfaction. Eating disorders as a symptom of depression are emotionally associated with loss of satisfaction which lead to the reduction of biological activity needs such as eating, drinking, and sexual activities. Moreover, eating disorder is physical depressions, which are loss of appetite and sleep disorders.

This means that eating disorders was caused by the depression of the individual, therefore, the depression emotionally and physically trigger the eating disorders of individuals.

Similar result can be seen on a study by Dahlmann et al., (2015) which discussed about the results of eating behavior and disorder in adolescents and their body mass index and population-based psychological function in Germany with a total of 771 participants (420 female and 351 male). The range of the age is 11-17 years old. The results showed a high score on eating disorders which is significantly occurred in adolescents with overweight and the emergence of depression symptoms. Early symptoms of depression show a significant 
relationship with overweight body and obesity in youth. There was a significant relationship between eating disorder symptoms and poor mental health in overweight during their youth. Obese adolescents who are depressed should be supervised for eating disorders that might occur.

\section{The effect of obesity or overweight on the quality of life}

The results showed that obesity and overweight in adolescents was indirectly affect the quality of life through depression in negative way.

The depression can be biologically and psychologically seen. Biologically, obesity or overweight is a condition of inflammation, because weight gain has been shown to activate the inflammatory pathways in the body, and the inflammation lead to depression. Hypothalamus Pituitary Adrenal axis (HPA axis) has a role in this case. Obesity involves the dysregulation of the HPA axis and it is involved in the occurrence of depression (Pasquali and Vicennati, 2000). Moreover, obesity lead to an increased risk of diabetes mellitus and an increase in insulin resistance that can cause changes in brain and increase the risk of depression (Shoelson et al, 2007).

Beside biological mechanisms, the depression that be caused by obesity and overweight can also be described by psychological mechanisms. Depression is an emotional response, and the characteristics are despair, reduced motivation, low self-esteem, slow thinking process, psychomotor retardation and eating and sleeping disorders. Obesity, overweight and perception can increase psychological pressure (Atlantis dan Ball, 2008).

Some people still think and believe that being skinny is a form of beauty, beauty is considered as social acceptance and sociocultural factors. It increases body dissatisfaction and reduces self-esteem, which can lead to depression. Diet, eating disorders and physical pain as a direct consequence of obesity, also known as the aspects which can increase the risk of depression (Derenne and Beresin, 2014).

Depression means having mental and emotional disorders. While the scope of life quality are emotional, social and physical welfare. An individual who is depressed means that he/she has poor emotional welfare. Individuals with poor emotional welfare will obviously degrade their quality of life, because emotional welfare is one of the aspects in life quality's assessment of an individual. (Fabricatore et al, 2005).

Similar result is shown in a study conducted by Morrison et al. (2015), it is stated that depressive symptoms were evaluated using the Depression of Epidemiology Classroom Questionnaire for Children and the quality of life with 4.0 PedsQL. The results of multivariate analysis showed that obesity rates had an effect on the depression and low quality of life.

\footnotetext{
REFERENCES

Ahrens W, Pigeot I (2015). Risk Factors of Childhood Obesity: Lessons from the European IDEFICS Study. In M.L. Frelut (Ed.), The ECOG's eBook on Child and Adolescent Obesity.

Alleva JM, Lange W, Jansen A dan Martijn C (2014). Negative Body Evaluation Predicts Overestimation of Negative Social Feedback. Science Direct; 11(3): 228-232.

Alvani SR, Hosseini SMP, Kimura LW (2015). Relationship between Body Weight and Self Esteem: A Study of Young Men and Women in Iran. Journal of Obesity and Overweight; 2(2): 1-8.
} 
Journal of Epidemiology and Public Health (2018), 3(2): 105-117

https://doi.org/10.26911/jepublichealth.2018.03.02.01

Alvarez A, Brodsky JB, Lemmens HJM, Morton JM (2010). Morbid Obesity Peri-Operative Management. New York: Cambridge University Press

Anderson SE, Cohen EN, Naumova, PF, Jacques A, Must (2007). Adolescent Obesity and Risk for Subsequent Major Depressive Disorder and Anxiety Disorder: Prospective Evidence. Psychosom Med.; 69(8): 740-7.

Atlantis E, Ball K (2008). Association Between Weight Perception and Psychological Distress. Internatioanl Journal of Obesity; 32: 715-721.

Baghci D dan Preuss HG. 2013. Obesity: Epidemiology, Pathophysiology, and revention, Second Edition. CRC Press Taylor \& Francis Group: New York

Braet C, Verbeken S (2015). Psychological Assessment of the Obese Child and Adolescents: Priciples. In M.L. Frelut (Ed.), The ECOG's eBook on Child and Adolescent Obesity.

Brown BB, Prinstein JM (2011). Encyclopedia of Adolescence. Elsevier's Science and Technology Rights Department in Oxford: United Kingdom.

Centers for Disease Control and Prevention (CDC). 2015. About Child and Teen BMI. Available from: https://www.cdc.gov/healthyweight/assessing/bmi /childrens_bmi/about_childrens_bmi.html. (Diakses 17 Juni 2017).

Centers for Disease Control and Prevention (CDC) (2017). Childhood Obesity Facts. Available from: https://www.cdc.gov/healthyschools/obesity/facts.htm. (Diakses 17 Juni 2017). (2016). Health-Related Quality of Life Concepts. Available from: https://www.cdc.gov/hrqol/concept.htm.

(Diakses 17 Juni 2017).

(2015). Measuring Children's Height and Weight Accurately at Home. Available from: https://www.cdc.- gov/healthyweight/assessing/bmi/childrens_bmi/measuring_child ren.html. (Diakses 17 Juni 2017).

Cherry AL, Baltag V, Dillon ME (2017). International Handbook on Adolescent Health and Development, The Public Health Response. Springer Internatioanl Publishing: Switzerland.

Dahlmann BH, Dempfle A, Konrad K, Klasen F, Sieberer UR 2015. Eating Disorder Symptoms Do Not Just Disappear: The Implications of Adolescent Eating-Disordered Behaviour for Body Weight and Mental Health in Young Adulthood. European Child and Adolescent Psychiatry Springer Link; 24(6): 675-684.

Danielsen YS, Kjell M, Inger H, Magne, Sand L, Ekornas B, Pallesen S. 2012. Factors Associated with Low Esteem in Children with Overweight. The European Journal of Obesity. 5: 722733.

Derene JL, Beresin EV (2014). Body Image, Media, and Eating Disorders. Academic Psychiatry; 30(3): 257-261.

Docherty JP, Sack DA, Roffman M, Finch M, Komorowski JK (2005). A DoubleBlind, Placebo-Controlled, Exploratory Trial of Chromium Picolinate in A Typical Depression: Effect on Carbohydrate Craving. J Psychiatr Pract. 11(5): 302-14.

Eddy KT, Tabri N, Thomas JJ, Murray HB, Keshaviah A, Hastings E, Franko DL (2016). Recovery From Anorexia Nervosa and Bulimia Nervosa at 22-Year Follow-Up. The Journal of Clinical Psychiatry.

Erermis S, Cetin N, Tamar M, Bukusoglu N, Akdeniz F, Goksen D (2004). Is Obesity A Risk Factor for Psychopathology among Adolescents. Pediatric Int. 46(3): 296-301. 
Fabricatore AN, Wadden TA, Sarwer DB, Faith MS (2005). Health-Related Quality of Life and Symptoms of Depression in Extremely Obese Persons Seeking Bariatric Surgery. Obesity Surgery; 15: 304-309.

Franklin JG, Denyer KS, Steinbeck, Caterson ID, Hill AJ (2006). Obesity and Risk of Low Self-Esteem: A Statewide Survey of Australian Children. Pediatrics.; 118(6): 2481-7.

Jacobi C, Fittig E (2010). Psychosocial Risk Factors for Eating Disorders. In Agras, W.S. (Ed.), Oxford Handbook of Eating Disorders. Oxford University Press: New York.

Keputusan Menteri Kesehatan Republik Indonesia Nomor 1995/ Menkes/ SK/ XII/ 2010 tentang Standar Antropometri Penilaian Status Gizi Anak.

Klaczynski PA, Goold KW, Mudry JJ (2004). Culture, Obesity Stereotypes, Self Esteem, and the Thin Ideal: A Social Identity Perspective. Journal of Youth and Adolescence; 33(4): 307317.

Kurniawan MY, Briawan D, Caraka RE (2015). Persepsi Tubuh dan Gangguan Makan pada Remaja. Jurnal Gizi Klinik Indonesia.; 11(3): 105-114.

Lubis NL (2016). Depresi: Tinjauan Psikologi. Kencana: Jakarta.

Luppino FS, Wit LM, Bouvy PF (2010). Overweight, Obesity, and Depression: A Systematic Review and Metaanalysis of Longitudinal Studies. Jama Psychiatry; 67 (3): 220-229.

Masdar H, Saputri PA, Rosdiana D, Chandra F, Darmawi (2016). Depresi, Ansietas dan Stres serta Hubungannya dengan Obesitas pada Remaja. Jurnal Gizi Klinik Indonesia.; 12(4): 138-143.

McClain Z, Peebles R (2016). Body Image and Eating Disorders Among Lesbian,
Gay, Bisexual, and Transgender Youth. Pediatric Clinics of North America

McClanahan KK, Huff MB, Omar HA (2009). Overweight Children and Adolescents: Impact on Psychological and Social Development. Pediatrics Faculty Publications. 140.

Mitchell JE, Crow S (2006). Medical Complications of Anorexia Nervosa and Bulimia Nervosa. Current Opinion in Psychiatry.; 19(4): 438-443

Mondimore FM, Patrick K (2015). Adolescent Depression: A Guide for Parents Second Edition. Johns Hopkins University Press: United States of America.

Morgan PJ, Okely AD, Cliff DP, Jones RA, Baur LA (2008). Correlates of Objectively Measured Physical Activity in Obese Children. Obesity. 16(12): 2634-41.

Morrison KM, Shin S, Tarnopolsky M, Taylor VH (2015). Association of Depression and Health Related Quality of Life with Body Composition in Children and Youth with Obesity. Journal of Affective Disorders Science Direct; 172: 18-23.

Mustillo S, Worthman C, Erkanli A, Keeler G, Angold A, Costello EJ (2003). Obesity and Psychiatric Disorder: Developmental Trajectories. Pediatrics.; 111 (4 Pt 1): 851-9.

NEDA Feeding Hope (2016). What is Body Image? Available from: https://www.nationaleatingdisorders.org/whatbody-image. (Diakses 11 Juni 2017).

Nieman P, LeBlanc CMA (2012). Canadian Paediatric Society, Healthy Active Living and Sports Medicine Committee Abridged Version: Paediatric Child Health. 17(3): 205-6

Ozmen D, Ozmen E, Ergin D, Cetinkaya AC, Sen N, Dundar PE, Taskin E, Oryal 
Journal of Epidemiology and Public Health (2018), 3(2): 105-117

https://doi.org/10.26911/jepublichealth.2018.03.02.01

(2007). The Association of SelfEsteem, Depression and Body Satisfaction with Obesity among Turkish Adolescents. BMC Public Health. 7: 80.

Papalia DE, Olds SW, Feldman RD (2008). Human Development (Psikologi Perkembangan Edisi ke 9). Jakarta: Kencana.

Pasquali R dan Vicennati V (2000). Activity of The Hipothalamic-Pituitary-Adrenal Axis in Different Obesity Phenotypes. International Journal of Obesity; 24: S47-S49.

Perrin EM, Boone-Helnonen J, Field AE, Coyne-Beasley T, Gordon-Larsen P (2010). Perception of Overweight and Self-Esteem during Adolescence. NIH Public Access. 43(5): 447-454.

Pujiastuti E, Fadlyana E, Garna H (2013). Perbandingan Masalah Psikososial pada Remaja Obes dan Gizi Normal Menggunakan Pediatric Symptom Checklist (PSC)-17, Sari Pediatri, 15(4).

Pusat Data dan Statistik Pendidikan-Kebudayaan (2017). Kementerian Pendidikan dan Kebudayaan.

Rankin J (2016). Psychological Consequences of Childhood Obesity: Psychiatric Comorbidity and Prevention. Adolescent Health Medicine and Therapeutics. 7: 125-146.

Rie SML, Noordenbos G, Furth EFV (2015). Quality of Life and Eating Disorders. Springer Link Quality of Life Research; 14(6): 1511-1521.

Riset Kesehatan Dasar (2013). Badan Penelitian dan Pengembangan Kesehatan Kementerian Kesehatan Republik Indonesia

Riset Kesehatan Dasar dalam Angka Provinsi Jawa Tengah (2013). Badan Penelitian dan Pengembangan Kese- hatan Kementerian Kesehatan Republik Indonesia.

Roberts RE, Hao DT (2013). Obesity Has Few Effects on Future Psychosocial Functioning of Adolescents. National Institutes of Health. 14(2): 128-136.

Shoelson, Steven E, Herrero L, Naaz A (2007). Obesity, Inflammation and Insulin Resistance. Official Journal of The Aga Institute Gastroenterology; 132(6): 2169-2180.

Smetaina N, Albaviciute E, Babinska V, Karinauskiene L, Albertsson-Wikland $\mathrm{K}$, Petrauskiene A, Verkauskiene R (2015). Prevalence of Overweight/ Obesity in Relation to Dietary Habits and Lifestyle Among 7-17 Years Old Children and Adolescents in Lithuania. BMC Public Health. 15: 1001

Stanford Children's Health (2017). Obesity in Adolescents.. Available from: http://www.stanfordchildrens.org/en/topic/default?id=obesity-in-adolescents-90-P01627. (Diakses 11 Juni 2017).

Vaidya V (2006). Psychosocial Aspects of Obesity. Adv Psychosom Med. 27: 7385.

Wahab AS (2000). Ilmu Kesehatan Anak Nelson Volume 1 E/15. Buku Kedokteran EGC: Jakarta.

Washington RL (2011). Childhood obesity: Issues of Weight Bias. Prev Chronic Dis. 8(5): A94.

Wille N, Bullinger M, Holl R, Hoffmeister U, Mann R, Goldapp C, Reinehr T, Westenhofer J, Egmond-Froehlich A, Ravens-Sleberer U (2010). Healthrelated Quality of Life in Overweight and Obese Youths: Results of A Multicenter Study. Health and Quality of Life Outcomes. 8: 36.

WHO 2017. Adolescent Health. Available from: http://www.who.int/topics/- 
Almasith et al./ Path Analysis on the Psychosocial Impact of Obesity

adolescent_health/en/. (Diakses 17 Juni 2017).

(2017). Maternal, Newborn, Child and Adolescent Health. Available from: http://www.who.int/maternal_child_adolescent/topics/adolescence/development/en/. (Diakses 17 Juni

2017).

(2016a). Adolescents: Health Risks and Solutions. WHO Regional Offices: Media Centre Fact Sheet.

(2016b). Obesity and Overweight. WHO Regional Offices: Media Centre Fact Sheet. 